\title{
Educating Practices at Primary School Level and New Forms of Positive Welfare for Families
}

\author{
Suzanne Gatt* and Laura Sue Armeni** \\ * Faculty of Education, University of Malta \\ E-mail: suzanne.gatt@um.edu.mt \\ **Malta Council for Science and Technology \\ E-mail: laurasue.armeni@gov.mt
}

The global financial crisis across Europe has created great societal demands. Social inclusion has become one of the main challenges of the millennium with those hit hardest being the most vulnerable people. It is at such times that it becomes crucial to provide positive welfare. This article presents research results from a transnational study, INCLUD-ED, an FP6 project of the European Commission, which focuses on educational practices promoting social cohesion as a form of positive welfare. The research focuses on six successful schools in five countries that have demonstrated that they can transform children's academic performance as well as have an impact on the community itself. A number of positive transformative approaches beyond better academic performance included a spill over of benefits to the schools' neighbouring communities and an increase in social cohesion and community in health, housing, employment and social and political participation was also identified.

Keywords: Education, community involvement, social innovation, positive welfare, social inclusion.

\section{Introduction}

Europe is currently facing many challenges, such as technological change, globalisation, energy and food safety, climate change, transformations of gender roles, migrations, economic and social exclusion and the ageing of the population (BEPA, 2010: 7). However, the current financial crisis and its effect on employment across the different EU member states is the greatest problem, which, like a plague, is wiping away the level of quality of life which Europe had achieved (European Foundation for the Improvement of Living and Working Conditions, 2012). At such times, social welfare plays a crucial role. As money becomes scarce and more people require social support, the need for positive welfare systems increases. The EU2020 Strategy (European Commission, 2010: 18) has already addressed this challenge, to a degree, and called for social innovation. Social innovation mobilises people's creativity and leads to the development of solutions which make better use of existing scarce resources (BEPA, 2010: 7). This article is about one type of social innovation, where successful schools across five European countries managed to provide help and support to families over and above the educational services which they would normally provide to children in the community. In the model identified, schools and community groups work together, mainly with the aim of providing a better 
education for children. However, participation has also developed into a form of positive welfare as those involved in the schools' activities experienced transformation through benefits related to housing, health, employment, social and political participation. All this was achieved at no additional cost to the schools or to governments.

\section{Theoretical background}

The creation of a welfare state is an expression of social responsibility by governments towards vulnerable groups in society such as older people, unemployed people and disabled people (Pearson, 1999: 30). Welfare provision can be either positive or negative. Negative welfare involves the provision of income support without any reciprocity. The state, as the powerful entity, distributes resources and delivers services to powerless people. The responsibility, power and activity lies with the provider, while passivity, reliance and dependency is expected from the receiver, who is considered the inferior party. In negative welfare, the state is reluctant to transfer responsibility to the people on the ground (Pearson, 1999: 33). Positive welfare, on the other hand, is different, in that social security is considered as a means of social inclusion, tackling different dimensions, such as status, lifestyle, employment, economic and political participation (Walker, 1998: 78). Recipients of social security are more likely to feel positive, pro-active and part of society. Positive welfare initiatives include offering people education, high-quality training and real work experience where people on benefit use their time to good effect (Walker, 1998: 80).

In the current economic climate, educating children has become a great challenge, as key players must operate with fewer resources and continual financial cuts (Chang, 2010: 14). Educational provision becomes a more important social service which governments can provide to citizens. Educating future generations, whilst promoting equity, also requires the input and effort of a wider range of players other than traditional teachers. This is particularly the case as different types of professional knowledge are necessary to tackle the social, educational and psychological needs of the students attending school and their families (Green at al., 2003: 19).

Schools can no longer be expected to be the single agents catering for all of the children's needs. Within a social perspective of positive welfare, in order to assist children in the best possible way, schools have to involve and share their responsibility with all the other agents in the children's lives including the families and the community within which they live. The community can provide human resources which often come for free. Furthermore, communities are able to access and operationalise existing resources and take pro-active and reactive action. Communities also give their members a sense of belonging, enhancing cohesion through commitment and diversity (Watkins, 2007: 44). Success in education, coupled with family involvement, promotes social capital (Green and Preston, 2001: 248). Thus, any government aiming to increase social capital and social inclusion must also focus on the quality of provision of education (Putnam, 2004).

\section{Methodology}

The research reported here stems from the INCLUD-ED (Strategies for Inclusion and Social Cohesion in Europe from Education) project, and is based on international insights (Castells et al., 1999) that in the context of the European knowledge-based society, educational success is the key to overcoming social exclusion and unemployment. 
INCLUD-ED considers social cohesion from a wide perspective, and the research results reported here refer to one sub-project that focused on learning communities through community involvement. A clear conceptualisation of educational success enables us to identify and evaluate the impact of inclusive and innovative approaches to education within specific community settings.

Educational success, according to the European Report on the Quality of School Education (European Commission, Directorate-General for Education and Culture, 2001: $33)$, is defined as a decrease in dropout rates, the completion of upper secondary education and participation in tertiary education. The main objective of the research was to identify whether family and community involvement within the educational setting resulted in higher educational achievement. It also sought to explore how community involvement in schools was empowering participants and promoting social cohesion within the neighbourhood. A mixed methodology utilising qualitative and quantitative approaches was used. The main methodological framework of the study was based on the critical communicative methodology approach, which is built on an egalitarian dialogue between researchers and social agents, vulnerable groups, educators, policy makers, employers, professionals and citizens as a whole (Flecha and Gomez, 2004: 88). This methodology allowed research findings to be categorised into two main perspectives: those which can be considered as transformative as they promote social cohesion; and those which are exclusionary, bringing about greater social exclusion.

The research questions

A number of research questions were set during the last year of the longitudinal study which probed the different forms of positive welfare that emerged beyond the scope of helping children with their educational achievements. The research questions focused on different aspects related to social cohesion and included: lifelong learning, health, housing, employment and political participation. The research questions posed included:

- In what ways, if any, has the participation in lifelong learning and the opportunities to improve it been transformed in the neighbourhood in relation to community participation in the school?

- In what ways, if any, have housing conditions and opportunities to improve them been transformed in the neighbourhood in relation to community participation in the school?

- In what way, if any, has health status and the opportunities to improve it been transformed in the neighbourhood in relation to community participation in the school?

- In what way, if any, has current social and political participation and opportunities to improve it been transformed in the neighbourhood in relation to community participation in the school?

- In what way, if any, has the employment situation and opportunities to improve it been transformed in the neighbourhood in relation to community participation in the school?

The context

The study was carried out in six schools across five countries. These schools were considered as successful schools fulfilling the following three criteria: (a) educational 
centres demonstrating a degree of contribution to school success (indicated by children's or adolescents' educational attainment) in relation to their context; (b) educational centres that respond to the same social characteristics - low socio-economic status and students with minority background; (c) educational centres with strong community involvement that are contributing to the ability to overcome existing inequalities. Each partner country had to consider any external evaluation assessment results as well as other measures to ensure that schools selected fitted the criteria set. Details relating to this can be found in the final Report (INCLUD-ED, 2010: 20). All the schools, involved in the research from Malta, the UK, Lithuania and Spain were primary schools whereas the school in Finland was a pre-school. The research was a four-year longitudinal study, with evolving research questions from one round of data collection to another.

The research tools

A mixed methodology approach was adopted, utilising quantitative and qualitative tools. The quantitative tools consisted of two sets of questionnaires, one addressed to pupils and the other to their guardians. A variety of qualitative tools were used, ranging from openended interviews, life stories and focus group interviews, to communicative observations.

Quantitative tools. The two questionnaires, one for parents and one for students, were designed specifically to elicit the impressions, opinions and perceived impact of the selected schools' success from the perspective of the end-users, from a longitudinal perspective. Questionnaires were administered for each of the four years, varying according to the nature of the specific research questions as the research evolved.

The family questionnaire. The family questionnaire in the fourth year consisted of twentynine items and included five different foci. The first part of the questionnaire focused on the respondents' demographics by gathering personal data about the guardians. The first eleven items involved questions relating to gender, age, relationship with the children, culture, religious belief, work situation and highest level of education.

The questionnaire (items 12-14) then focused on the family's level of satisfaction with the school and how the school was spoken of within the community. These questions led to more specific questions (items 15-18) about the children's degree of improvement in specific subject areas as well as overall academically. The fourth part focused on the family's expectations with respect to the secondary and tertiary education of their children as well as for the future (items 19-20). The last part of the questionnaire (items 21-29) focused on community involvement, probing various aspects such as ways in which the community is involved in the school, how they as family members participate, reasons for not participating if this is the case, the benefits of community involvement and opportunities to meet other parents.

The children's questionnaire. The children's questionnaire was structured similarly to that for the family. It consisted of twenty-four items. The first section (items 1-10) included items about the personal details. such as gender, age, nationality, culture and religion, as well as with whom they lived and their jobs. The questionnaire then probed how well they thought they were doing at school and in specific subject areas (items 11-14). The third part focused on aspirations (items 15-17) and asked the children to indicate whether they wanted to proceed to secondary and tertiary education and how much they valued their 
education in terms of their future. The last part of the questionnaire (items 18-24) focused on community involvement and asked the children to indicate who usually participated in the school other than the teachers and what other community activities they participated in.

Over the period of four years, a total of 4,484 questionnaires were collected for all the case studies. Table 1 presents a summary of the questionnaires collected in each of the five countries.

Qualitative tools. Qualitative tools included open-ended interviews, communicative life stories, communicative focus groups and communicative observations. Openended interviews were conducted with five representatives of the local administration, five representatives of other local community organisations and three interviews with professionals working in the local project. Thirteen daily life stories of end-users, five communicative observations and one communicative focus group were also conducted. The qualitative data provided rich insights into the degree of community involvement, evidence on the types of community involvement practices, strategies used by schools to encourage community involvement and achievements obtained, links between community involvement and learning and the impact of community involvement in school on the whole community.

\section{Results}

The research results will be considered from two perspectives: the first focusing on the impact on children's academic achievement; the second on how community involvement in school had impacted upon the wider community as a form of positive welfare. Previous research rounds identified key aspects of community involvement, including family education where family members themselves are involved in learning, participation in the decision-making process, participation in the development and evaluation of the curriculum and participation in classrooms and learning spaces. Utilising the communicative methodology, transformative and exclusionary practices were reported and examples of positive welfare were highlighted.

\section{Impact on school achievement}

The level of satisfaction with the school was probed in different ways in both questionnaires: through how the neighbourhood viewed the school and the children's and families' satisfaction with their experience at school.

Most of the parents in all of the six schools felt that the schools were well regarded in the neighbourhood. The highest levels were obtained in Spain and the United Kingdom, with nearly half of the families saying that the school was thought of very positively.

Families across all schools were quite satisfied with the service and support provided by the school. The highest percentages were again obtained in the schools in Spain and the United Kingdom.

The children's questionnaire also shows that most of the children were happy at the school they attended. Over 60 per cent of the students in all countries except the United Kingdom stated that they were very happy. The least happy responses obtained were those from students in the United Kingdom, where children showed a less positive picture than 
Table 1 Summary of the questionnaires collected in each country for round

\begin{tabular}{|c|c|c|c|c|c|c|c|c|c|}
\hline \multirow[b]{3}{*}{ Country } & \multicolumn{9}{|c|}{ Questionnaires collected } \\
\hline & \multicolumn{2}{|c|}{1 st round } & \multicolumn{2}{|c|}{ 2nd round } & \multicolumn{2}{|c|}{3 rd round } & \multicolumn{2}{|c|}{4 th round } & \\
\hline & children & families & children & families & children & families & children & families & \\
\hline Finland & 20 & 19 & 20 & 19 & 7 & 7 & 5 & 5 & \\
\hline Lithuania & 27 & 19 & 99 & 51 & 119 & 85 & 73 & 86 & \\
\hline Malta & 249 & 232 & 88 & 83 & 229 & 245 & 217 & 225 & \\
\hline Spain & 224 & 37 & 220 & 50 & 236 & 102 & 204 & 290 & \\
\hline UK & 49 & 21 & 49 & 71 & 269 & 28 & 314 & 89 & \\
\hline TOTAL & 569 & 328 & 476 & 274 & 860 & 467 & 813 & 695 & 4,484 \\
\hline
\end{tabular}


Table 2 Summary of the qualitative techniques used in each school and round of Project 6

\begin{tabular}{|c|c|c|}
\hline \multicolumn{3}{|c|}{ Qualitative data collection } \\
\hline \multicolumn{3}{|c|}{ Existing data and documents } \\
\hline \multicolumn{3}{|c|}{13 Standardised open-ended interviews: } \\
\hline $\begin{array}{l}5 \text { representatives of } \\
\text { the local } \\
\text { administration } \\
\text { (working in } \\
\text { different areas of } \\
\text { society) }\end{array}$ & $\begin{array}{c}5 \text { representatives of } \\
\text { other community } \\
\text { organisations } \\
\text { involved in the } \\
\text { local project }\end{array}$ & $\begin{array}{l}3 \text { professionals } \\
\text { working in the } \\
\text { local project }\end{array}$ \\
\hline \multicolumn{3}{|c|}{13 Communicative daily life stories of end-users: } \\
\hline 6 family members & 7 students & \\
\hline \multicolumn{3}{|c|}{1 Communicative focus group } \\
\hline \multicolumn{3}{|c|}{1 group with professionals working in the local project } \\
\hline \multicolumn{3}{|c|}{5 Communicative observations: } \\
\hline \multicolumn{3}{|c|}{$\begin{array}{l}5 \text { observations looking at the characteristics and particularities of } \\
\text { each local project, in spaces in which community participation } \\
\text { could be found. }\end{array}$} \\
\hline \multicolumn{2}{|c|}{$\begin{array}{l}\text { Total techniques for each case studying every } \\
\text { round }\end{array}$} & 32 \\
\hline
\end{tabular}

their families. The highest percentages of very happy students were obtained in Malta and in Spain.

The children were also asked to indicate how much they felt that they had improved in mathematics, languages and overall. Children from all countries provided very positive responses, with around 70 per cent reporting a significant improvement. The highest selfexpectations in both mathematics and language learning were obtained by students from the school in Spain. The great majority of students in both Spain and the United Kingdom expected to do much better in the coming academic year. Positive responses were also obtained by students in Malta and Lithuania. Children in Finland were not asked this question as at the age of five they would not understand its meaning.

A picture similar to that expressed by the children was obtained from parents. The pattern was slightly less positive in ICT, compared with mathematics and language learning. With respect to overall achievement, many families expected their children to do better this academic year, but considerably fewer opted for the more positive choice of 'much better'.

\section{Community involvement as positive social welfare}

The last year of the longitudinal study focused on the impact of community involvement within the school on neighbouring surroundings and identified types of positive welfare. Data from the last year revealed a belief that community involvement had positively impacted on social aspects beyond schooling. such as housing, health, employment and social and political participation. Community involvement practised in the six schools researched was shown to be an effective instrument in alleviating some of the burdens 
Table 3 Qualitative and communicative data: data collected in the fourth year of the study

\begin{tabular}{|c|c|c|c|c|c|c|c|c|}
\hline & $\begin{array}{c}\text { Communicative } \\
\text { daily life series } \\
\text { of family } \\
\text { members }\end{array}$ & $\begin{array}{c}\text { Communicative } \\
\text { daily life series } \\
\text { of students }\end{array}$ & $\begin{array}{l}\text { Interviews with } \\
\text { professionals } \\
\text { working in the } \\
\text { project }\end{array}$ & $\begin{array}{l}\text { Interviews } \\
\text { with people } \\
\text { from other } \\
\text { organisa- } \\
\text { tions in the } \\
\text { community }\end{array}$ & $\begin{array}{l}\text { Interviews } \\
\text { with local } \\
\text { authority } \\
\text { employees }\end{array}$ & $\begin{array}{c}\text { Communicative } \\
\text { observations }\end{array}$ & $\begin{array}{l}\text { Communicative } \\
\text { Focus Group }\end{array}$ & Total \\
\hline Finland & 6 & 7 & 3 & 5 & 5 & 5 & 1 & 32 \\
\hline Lithuania & 6 & 13 & 3 & 5 & 5 & 5 & 1 & 38 \\
\hline Malta & 6 & 7 & 3 & 5 & 5 & 5 & 1 & 32 \\
\hline Spain & 16 & 14 & 9 & 10 & 10 & 3 & 1 & 63 \\
\hline $\begin{array}{l}\text { United } \\
\text { Kingdom }\end{array}$ & 6 & 7 & 3 & 5 & 5 & 5 & 1 & 32 \\
\hline TOTAL & 40 & 48 & 21 & 30 & 30 & 23 & 5 & 197 \\
\hline TOTAL & & 88 & & & 81 & & 28 & \\
\hline
\end{tabular}

Note: All the data gathered were analysed using a grid to identify transformative and exclusionary practices for the different forms of community involvement which emerged. 
Table 4 Frequency of how families feel that school is spoken of in the neighbourhood

\begin{tabular}{|c|c|c|c|c|c|c|c|c|c|c|}
\hline & \multicolumn{2}{|c|}{ Finland } & \multicolumn{2}{|c|}{ Lithuania } & \multicolumn{2}{|c|}{ Malta } & \multicolumn{2}{|c|}{ Spain } & \multicolumn{2}{|c|}{$\begin{array}{l}\text { United } \\
\text { Kingdom }\end{array}$} \\
\hline & $N$ & $\%$ & $N$ & $\%$ & $N$ & $\%$ & N & $\%$ & $N$ & $\%$ \\
\hline Very positively & 1 & 20 & 18 & 24.7 & 52 & 24.2 & 42 & 48.3 & 38 & 44.2 \\
\hline Quite positively & 4 & 80 & 37 & 50.7 & 117 & 54.4 & 25 & 28.7 & 42 & 48.8 \\
\hline More or less positively & - & - & 18 & 24.7 & 45 & 20.9 & 19 & 21.8 & 6 & 7.0 \\
\hline Badly & - & - & - & - & 1 & 0.5 & 1 & 1.1 & - & - \\
\hline TOTAL & 4 & 4 & 73 & 100 & 215 & 100 & 87 & 100 & 86 & 100 \\
\hline
\end{tabular}

Table 5 Frequency of how much families are satisfied with the school

\begin{tabular}{|c|c|c|c|c|c|c|c|c|c|c|}
\hline & \multicolumn{2}{|c|}{ Finland } & \multicolumn{2}{|c|}{ Lithuania } & \multicolumn{2}{|c|}{ Malta } & \multicolumn{2}{|c|}{ Spain } & \multicolumn{2}{|c|}{$\begin{array}{l}\text { United } \\
\text { Kingdom }\end{array}$} \\
\hline & $N$ & $\%$ & $N$ & $\%$ & $N$ & $\%$ & $N$ & $\%$ & $N$ & $\%$ \\
\hline Very satisfied & 1 & 25 & 28 & 38.4 & 75 & 34.6 & 51 & 50.0 & 51 & 58.0 \\
\hline Quite satisfied & 3 & 75 & 35 & 47.9 & 112 & 51.6 & 30 & 29.4 & 31 & 35.2 \\
\hline More or less satisfied & - & - & 7 & 9.6 & 24 & 11.1 & 20 & 19.6 & 6 & 6.8 \\
\hline Not at all satisfied & - & - & 3 & 4.1 & 6 & 2.8 & 1 & 1.0 & - & - \\
\hline TOTAL & 4 & 100 & 73 & 100 & 217 & 100 & 102 & 100 & 88 & 100 \\
\hline
\end{tabular}

Table 6 Frequency of how happy children are at the school

\begin{tabular}{|c|c|c|c|c|c|c|c|c|c|c|}
\hline & \multicolumn{2}{|c|}{ Finland } & \multicolumn{2}{|c|}{ Lithuania } & \multicolumn{2}{|c|}{ Malta } & \multicolumn{2}{|c|}{ Spain } & \multicolumn{2}{|c|}{$\begin{array}{l}\text { United } \\
\text { Kingdom }\end{array}$} \\
\hline & $N$ & $\%$ & $N$ & $\%$ & $N$ & $\%$ & $N$ & $\%$ & $N$ & $\%$ \\
\hline Very happy & 3 & 60 & 58 & 67.4 & 197 & 86.4 & 208 & 88.5 & 157 & 50.5 \\
\hline Not very happy & 2 & 40 & 12 & 14.0 & 28 & 12.3 & 24 & 10.2 & 146 & 46.9 \\
\hline Not happy at all & - & - & 16 & 18.6 & 3 & 1.3 & 3 & 1.3 & 8 & 2.6 \\
\hline TOTAL & 5 & 100 & 86 & 100 & 228 & 100 & 235 & 100 & 311 & 100 \\
\hline
\end{tabular}

arising from the economic recession, providing support and help to families at such crucial times. This is particularly significant as families tend to be reluctant to seek help and support from official government entities due to barriers arising from the perceived stigma associated with those using social or specialist services. Moreover, some groups experience barriers such as language and cultural differences, making access difficult. The schools, through their involvement in community activities, have taken on part of this responsibility. Tools identified as assisting schools with community involvement included the inclusion of a parent liaison officer in England, local council and NGOs' input in Malta, and groups of parents in Finland who organised themselves to help other parents. 
Table 7 Frequency of how the children feel they have improved in mathematics and language as well as how much better they believe that they will do in the academic year

\begin{tabular}{|c|c|c|c|c|c|c|c|c|c|c|}
\hline & \multicolumn{2}{|c|}{ Finland } & \multicolumn{2}{|c|}{ Lithuania } & \multicolumn{2}{|c|}{ Malta } & \multicolumn{2}{|c|}{ Spain } & \multicolumn{2}{|c|}{$\begin{array}{l}\text { United } \\
\text { Kingdom }\end{array}$} \\
\hline & $N$ & $\%$ & $N$ & $\%$ & $N$ & $\%$ & $N$ & $\%$ & $N$ & $\%$ \\
\hline \multicolumn{11}{|c|}{ Improvement in mathematics } \\
\hline Very much & 3 & 60 & 61 & 70.9 & 160 & 69.6 & 196 & 83.8 & 211 & 68.1 \\
\hline A little & 2 & 40 & 22 & 25.6 & 62 & 27.0 & 33 & 14.1 & 93 & 30.0 \\
\hline Not at all & - & - & 3 & 3.5 & 8 & 3.5 & 5 & 2.1 & 6 & 1.9 \\
\hline Total & 5 & 100 & 86 & 100 & 230 & 100 & 234 & 100 & 310 & 100 \\
\hline \multicolumn{11}{|c|}{ Improvement in language } \\
\hline Very much & 4 & 80 & 60 & 69.8 & 151 & 66.2 & 193 & 82.5 & 202 & 67.6 \\
\hline A little & 1 & 20 & 26 & 30.2 & 38 & 31.1 & 38 & 16.2 & 93 & 31.1 \\
\hline Not at all & - & - & - & - & 3 & 2.6 & 3 & 1.3 & 4 & 1.3 \\
\hline Total & 5 & 100 & 86 & 100 & 234 & 100 & 234 & 100 & 299 & 100 \\
\hline \multicolumn{11}{|c|}{ Expectations of performance in coming academic year } \\
\hline Better & $\mathrm{n} / \mathrm{a}^{*}$ & $\mathrm{n} / \mathrm{a}$ & 57 & 68.5 & 172 & 74.8 & 209 & 88.9 & 275 & 88.1 \\
\hline The same & $\mathrm{n} / \mathrm{a}$ & $\mathrm{n} / \mathrm{a}$ & 23 & 28.0 & 55 & 23.9 & 24 & 10.2 & 29 & 9.3 \\
\hline Worse & $\mathrm{n} / \mathrm{a}$ & $\mathrm{n} / \mathrm{a}$ & 2 & 2.4 & 3 & 1.3 & 2 & 0.9 & 8 & 2.6 \\
\hline Total & $\mathrm{n} / \mathrm{a}$ & $\mathrm{n} / \mathrm{a}$ & 82 & 100 & 230 & 100 & 235 & 100 & 312 & 100 \\
\hline
\end{tabular}

Note: * Item not included in the pre-primary questionnaire.

\section{Housing}

Adequate housing, defined as decent and clean dwellings, is an essential aspect of an acceptable quality of life. A number of aspects related to housing which can lead to social exclusion were identified within the research.

Exclusionary aspects. The financial crisis had an impact on many neighbourhoods across Europe. In Spain, some families sent some of their members to their native country. This created a new family nucleus, often of men sharing a house and expenses. This situation was found to be susceptible to conflict, particularly in overcrowded living conditions. In Malta, the financial crisis has led to government cuts in social housing, resulting in less government support to those in most need. In Lithuania, families with previously stable mortgages found themselves without income, leading to mortgage arrears and many repossessions. Further, it was also found that the needs of some immigrant families with culturally defined extended families were not being met. Families were often forced to live in overcrowded conditions. It was particularly difficult for Moroccan families to find decent housing which accommodated all the family members.

Transformative aspects. Community involvement in the schools impacted differentially upon distinct aspects of housing in the neighbourhood. Accessing housing advice was significant. In Finland, the school had a family worker responsible for helping families with housing and other difficulties. The school in England employed a parent liaison officer who communicated in both English and Punjabi to enable families to access housing 
Table 8 Frequency of how the families feel their children have improved in mathematics, language and ICT, as well as how much better they believe they will do in the academic year

\begin{tabular}{|c|c|c|c|c|c|c|c|c|c|c|}
\hline & \multicolumn{2}{|c|}{ Finland } & \multicolumn{2}{|c|}{ Lithuania } & \multicolumn{2}{|c|}{ Malta } & \multicolumn{2}{|c|}{ Spain } & \multicolumn{2}{|c|}{$\begin{array}{c}\text { United } \\
\text { Kingdom }\end{array}$} \\
\hline & N & $\%$ & $N$ & $\%$ & $N$ & $\%$ & $N$ & $\%$ & $N$ & $\%$ \\
\hline \multicolumn{11}{|c|}{ Improvement in mathematics } \\
\hline Very much & 3 & 60 & 33 & 45.2 & 38 & 17.7 & 57 & 55.3 & 36 & 40.4 \\
\hline Quite a lot & 2 & 40 & 29 & 39.7 & 139 & 64.7 & 31 & 30.1 & 36 & 40.4 \\
\hline A little & - & - & 8 & 11.0 & 36 & 16.7 & 14 & 13.6 & 15 & 16.9 \\
\hline Not at all & - & - & 3 & 4.1 & 2 & 0.9 & 1 & 1.0 & 2 & 2.2 \\
\hline Total & 5 & 100 & 73 & 100 & 215 & 100 & 103 & 100 & 89 & 100 \\
\hline \multicolumn{11}{|c|}{ Improvement in language } \\
\hline Very much & 1 & 20 & 36 & 49.3 & 42 & 20.4 & 40 & 39.2 & 39 & 43.8 \\
\hline Quite a lot & 3 & 60 & 34 & 46.6 & 129 & 62.6 & 31 & 30.4 & 36 & 40.4 \\
\hline A little & 1 & 20 & 1 & 1.4 & 35 & 17.0 & 21 & 20.6 & 11 & 12.4 \\
\hline Not at all & - & - & 2 & 2.7 & - & - & 10 & 9.8 & 3 & 3.4 \\
\hline Total & 5 & 100 & 73 & 100 & 206 & 100 & 102 & 100 & 89 & 100 \\
\hline \multicolumn{11}{|c|}{ Improvement in ICT } \\
\hline Very much & 1 & 20 & 4 & 6.2 & 29 & 14.3 & 49 & 47.6 & 25 & 28.7 \\
\hline Quite a lot & 3 & 60 & 18 & 27.7 & 110 & 54.2 & 32 & 31.1 & 37 & 42.5 \\
\hline A little & 1 & 20 & 23 & 35.4 & 62 & 30.5 & 17 & 16.5 & 22 & 25.3 \\
\hline Not at all & - & - & 20 & 30.8 & 2 & 1.0 & 5 & 4.9 & 3 & 3.4 \\
\hline Total & 5 & 100 & 65 & 100 & 203 & 100 & 103 & 100 & 87 & 100 \\
\hline \multicolumn{11}{|c|}{ Expectations of performance in coming academic year } \\
\hline Much better & 2 & 40 & 12 & 16.4 & 28 & 13.3 & 30 & 29.7 & 49 & 55.7 \\
\hline Better & 3 & 60 & 40 & 54.8 & 175 & 83.3 & 38 & 37.6 & 37 & 42.0 \\
\hline The same & - & - & 20 & 27.4 & 7 & 3.3 & 22 & 21.8 & 2 & 2.2 \\
\hline Worse & - & - & 1 & 1.4 & - & - & 11 & 10.9 & - & - \\
\hline Total & 5 & 100 & 73 & 100 & 210 & 100 & 101 & 100 & 88 & 100 \\
\hline
\end{tabular}

benefit advice and support. This practice was a significant form of positive welfare. In Finland, schools also provided safe spaces for young people to enjoy themselves such as a youth centre which collaborated with the pre-school. This youth centre was an effective way of cultivating participation, volunteering and positive engagement of youth with the community (Ipsos MORI, 2010: 31). A group within the school also visited community locations urging businesses not to sell alcohol to those under age. Families involved in school activities used their skills and competences for the benefit of society.

The schools created social networks and associations. In England, the school allowed families to meet and form networks to share knowledge and information. In Malta, these networks served both to provide information and support to families. In one case, a collective effort enabled a family to furnish their home. In Spain, improvements in the local environment combined with the school's success attracted more people to the local neighbourhood. Also in Spain, the participation of migrants within wider networks enabled this group to understand the housing and banking system in Spain. Networking initiated and supported from within the school spread throughout the community 
overcoming exclusionary barriers relating to lack of knowledge, enabling families to improve their housing conditions.

Health

Exclusionary aspects. Various exclusionary aspects related to health were identified within the community and the school. As the global financial crisis placed more families in precarious situations due to lower income, aspects of quality of life decreased, including nutrition. In addition, the research identified racist perceptions relating to the health and hygiene levels of particular groups. The Spanish schools reported how immigrant populations were often perceived as having bad habits relating to basic healthcare. In Spain, the United Kingdom and Finland, it was found that families tended to place less importance on health, resulting in a fairly poor level of health awareness. In Lithuania, there was a lack of information related to health issues for families within the school. In Finland and Spain, many families were reluctant to use health services, and this was particularly the case among immigrant families, possibly due to language barriers.

Transformative aspects. The research showed how language learning within schools enabled participants to better understand what health services were available, how they worked and how to access them. Family learning also provided general skills, values and dispositions, among which one finds a higher satisfaction with one's own health (Cutler and Lleras-Muney, 2006: 16). It showed how investments in education and literacy, particularly for women, had an impact in the prevention of health problems (Sen, 1999: 190; Stein, 1997: 85).

Nearly all of the schools provided examples of projects and programmes which focussed on health issues and involved both children and their families. In Malta, the school participated in health awareness and support campaigns at national level. In England, the school organised healthy eating courses, information about lunches for children, changed the options of lunch snacks, sought links with local partnerships and government agencies and utilised expertise available at local level. In Lithuania, the school had a library where all community members could access computer resources or books related to health issues.

School and/or other community organisation initiatives to promote and support health services within the community were also identified. The school in Spain encouraged families to hand in their child's immunisation record card to the local doctor. Parents learnt how to react immediately to a call for vaccination and most children completed all their required vaccinations. In Finland, the school collaborated with the child health clinic to promote parents' use of the health services. In Malta, the local municipality has invested in its health centre, enabling more accessible health services.

\section{Employment}

Exclusionary aspects. A number of exclusionary aspects hindering access to employment and impacting negatively on social cohesion were identified. The global crisis has created a difficult financial situation with many families losing their main economic income. The loss of employment was felt in Malta, Lithuania and Spain, where families had few alternative opportunities. Barriers to access to the labour market were 
identified among vulnerable groups. In Spain, women suffered as husbands did not allow their wives to work, even if they found employment. Many immigrants in Finland had problems finding employment due to a combination of low levels of education, cultural differences and language barriers.

Transformative aspects. Actions and activities within the school were often designed to help families to obtain employment or increase employment opportunities. Those participating in family education courses increased their opportunities of finding work in different ways. In England, participants developed skills and competencies on a personal level, becoming better at looking for work and furthering their studies. There were instances where the volunteer work done at school increased chances of finding employment, as volunteering itself served as work experience. In Finland, Spain and England, families eventually found employment within the school itself. The volunteering work in combination with following courses equipped participants with skills and competences as well as hands on experience to be able to eventually find work within the school. Participants also served as role models to other members of the community as examples of success in finding employment and entering the labour market. In England, some parents went on to become teaching assistants, in Spain, a number of volunteers worked in the school canteen, while in Finland they were employed to work in the day-care centre.

People participating in school activities also built networks of contacts. Through these networks it was possible to find work. In Spain, a woman found work through a person she met at school. The school was also a source of information about employment. This was achieved in different ways. In England, the liaison officer provided help and support with information on employment and further education. In Finland, the school library received newspapers and journals, enabling members of the community to access information relating to employment opportunities. In Malta, the literacy unit in the locality provided a service on accessing employment opportunities.

\section{Social and political participation}

Exclusionary aspects. There were a number of factors which excluded members of the community from participating in the social and political activities in the community. In Finland, some families lacked enthusiasm and energy to participate in social and political activities. In Lithuania, those from low socio-economic backgrounds, who would have benefited most from social and political participation, were the least willing to participate. In Spain, families complained that they did not have time to participate in school activities. There were also particular groups of people who had difficulty participating in social activities due to their limited language skills. Many tended to not have all their official residency papers and so were anxious and insecure about being identified. Similarly, in Finland migrant groups were often socially isolated, excluded from the dominant language of the society and tended to communicate and participate only with those who shared their language.

Transformative aspects. A number of practices within the schools researched promoted social and political participation in other spheres of activity within their own neighbourhood. In Finland, participants formed an active group to tackle the selling of alcoholic drinks to youths over the counter as this was promoting alcohol problems 
within the neighbourhood. In Spain, participants also took part in other spheres of activity within the community. In Malta, one parent talked about her satisfaction in convincing other parents to participate, while in Spain people from the community who did not have any children attending the school also participated and contributed to activities within the school. In England, the school encouraged parents to participate in broader parental forums which included parents from other schools in the region.

\section{New welfare in action; education through community inclusion, transforming lives and learning}

This research has clearly evidenced how educating children through community involvement can act as a promising positive welfare strategy, addressing barriers to learning whilst enhancing healthy development for both school children and their families. Empowering families and students has been shown to result in both improved academic performance as well as a form of positive welfare for the community. Children developed educational resilience, enabling them to succeed academically despite social and psychological factors that could have hindered their progress. Children improved both in academic and non-academic fields. Gender stereotypes and gender roles were also slowly changed as women were empowered, and community members of different backgrounds integrated. Parental involvement and the up-skilling of parents' education through school or community initiatives proved successful, and also equipped parents to reinforce their children's academic improvement beyond the school walls.

The good reputation built by the schools operating as learning communities and the transformations which they brought about had a ripple effect on the communities which also grew positively in terms of image, often 'transforming ghettos'. This has resulted in increased numbers of students attending the schools. This was most clearly apparent in the two schools in Spain. The change in image has also helped families in Lithuania to better understand the work of educational staff.

Education has been shown to be one tool for reducing inequalities by fostering cognitive, social and emotional skills and promoting, among other things, healthy lifestyles (OECD, 2010: 12). Schools with community involvement have been shown to achieve this as the different community and educational agents work together for the benefit of all. This is how the educational interventions aimed at children and their families within the school were found to also promote and transform lives, particularly in healthcare and within neighbourhood settings. A high average level of education in a municipality is associated with longer life expectancy (Kravdal, 2009: 1030), and many of the schools researched have worked with the local community organisations to raise awareness and education about good health practices. The schools, through improving opportunities for employment, have worked successfully to overcome income inequality, promoting greater social cohesiveness and better population health within the communities that they serve.

By offering forms of help and support in terms of family education, participation in decision-making and other forms of community involvement, the schools have helped members of the community become active and pro-active participants in society. While community members were supporting the school in activities which were beneficial both to the children and to the community, they developed themselves, becoming active agents able to help themselves, integrate better and improve their life chances. This makes the support and help provided by schools a form of positive welfare. 
The schools researched have developed a form of social innovation in the provision of positive welfare, where transformation was achieved through reciprocity and implementation at community level (Pearson, 1999: 34). They illustrate the need to consider how changing the context of the individual services and activities interact with the quality of the services themselves (Jensen, 2011: 133). People can take more responsibility for societal challenges and outcomes if opportunities for intervention are available to them. The schools acted as catalysts in promoting pro-activity in managing inequalities of opportunity which are usually shaped by personality and peer culture (Martin and Taylor-Gooby, 2008: 16). A more important aspect of the example of positive welfare demonstrated is that schools operated within their same budget allocation, with results within and outside school walls obtained with the same budgetary limitations. This is one example of social innovation where more can be achieved with the same resources available.

\section{Conclusion}

This research has revealed how schools practising community involvement may really become the schools of the future (OECD, 2001), acting as a central point of reference to communities and particularly to those groups who need most help to integrate in society. Within increasingly multicultural societies across Europe, schools can capitalise on their historically central role within communities by working with communities to provide positive welfare provision. At a time of economic and social crisis and uncertainty, schools can help families face their financial, social and cultural challenges. Here, schools can support families in their search for identity within communities which are becoming more diverse with increased migration of different ethnic, cultural and religious groups.

Further research would usefully explore how schools can play a greater role within the community, going beyond the education of children for the future to pro-actively providing forms of support to families and communities as part of a positive welfare system. Governments across Europe have tended to invest in initiatives and support structures which are separate extraneous entities to the community, often reflecting a negative form of welfare. With established networks, schools are already firmly embedded within the community and it would be very useful to evaluate the potential value of injecting initiatives directly into schools as a more cost effective and successful way of promoting integration and social cohesion. Primary schools already have existing social networks within the community which can act as an effective vehicle, enabling governments to reach out to those who are most excluded in our societies. At a time when governments across Europe are searching for innovative solutions which are effective within relatively short periods of time, schools with community involvement can offer an approach which can lead to more positive solutions for all.

\section{Acknowledgements}

The research reported here is part of the FP6 Integrated Project INCLUD-ED funded by the European Commission. 


\section{References}

BEPA (Bureau of European Policy Advisers, European Commission) (2010) Empowering People, Driving Change, Social Innovation in the European Union, Luxembourg: Publications Office of the European Union.

Cutler, D. M. and Lleras-Muney, A. (2006) 'Education and health: evaluating theories and evidence', Working Paper 12352, National Bureau of Economic Research, Cambridge, www.nber.org/papers/ w12352 (accessed 13.09.2008).

Castells, M., Freire, P., Flecha, R., Giroux, H., Macedo, D. and Willis, P. (1999) Critical Education in the New Information Age, Lanham, MD: Roman \& Littlefield.

Chang, G. (2010) 'Monitoring the effects of the global crisis on education provision', Comparative Education, 12, 2, 14-20.

European Commission (2010) 'Communication from the Commission, Europe 2020: a strategy for Smart, sustainable and inclusive growth', Brussels: 3.3 .10 COM (2010) 2020.

European Commission, Directorate-General for Education and Culture (2001) European Report on the Quality of School Education: Sixteen Quality Indicators, Luxembourg: Office for Official Publications of the European Communities.

European Foundation for the Improvement of Living and Working Conditions (2012) Experiencing the Economic Crisis in the EU: Changes in Living Standards, Deprivation and Trust, Dublin: Eurofund.

Flecha, R. and Gomez, J. (2004) 'Participatory paradigms: researching "with" rather than "on"', in B. Crossan, J. Gallacher and M. Osborne (eds.), Researching Widening Access: Issues and Approaches in an International Context, London: Routledge.

Green, A. and Preston, J. (2001) 'Education and social cohesion: recentering the debate', Peabody Journal of Education, 76, 3/4, 247-84.

Green, A., Preston, J. and Sabates, R. (2003) 'Education, equality and social cohesion: a distributional approach', Compare, 33, 4, 453-70.

INCLUD-ED (2010) Working Papers: Case Studies of Local Projects in Europe (4th Round), Barcelona: CREA.

Ipsos MORI (2010) Every Child Matters - Exploring the Need of Vulnerable Young People in Kent: Qualitative Research Conducted with Young People and Parents/Carers Living in Kent, Maidstone: Kent County Council.

Jensen, C. (2011) 'Determinants of welfare service provision after the golden age', International Journal of Social Welfare, 20, 2, 125-34.

Kravdal, O. (2009) 'The importance of community education for individual mortality: a fixed-effects analysis of longitudinal multilevel data on 1.7 million Norwegian women and men', Journal of Epidemiology and Community Health, 64, 12, 1029-35.

Martin, R. and Taylor-Gooby, P. (2008) Fairness and the Welfare State: The Double Disconnect, Germany: The Anglo-German Foundation.

OECD (2001) Schooling for Tomorrow: What Schools for the Future? Paris: OECD, Centre for Educational Research and Innovation.

OECD (2010) Improving Health and Social Cohesion through Education, Paris: OECD, Centre for Educational Research and Innovation.

Pearson, N. (1999) 'Positive and negative welfare and Australia's indigenous communities', Family Matters, 54, Spring/Summer, 30-5.

Putnam, R. D. (2004) 'Education, diversity social cohesion and "social capital", raising the quality of learning for all', meeting of OECD Education Ministers, 18-19 March, OECD Education, Dublin, Ireland, Paris, pp. 1-8.

Sen, A. (1999) Development as Freedom, New York: Oxford University Press. 
Stein, J. (1997) Empowerment and Women's Health: Theory, Methods and Practice, London: Zed books.

Walker, K. (1998) 'Promoting positive welfare: social security is a great success story which facilitates economic change', New Economy, 5, 2, 77-82.

Watkins, K. (2007) Classrooms as Learning Communities: What's in It for Schools, London: Routledge. 
Reproduced with permission of the copyright owner. Further reproduction prohibited without permission. 